\title{
A Smart Oro-Soft Palate Mucosal Drug Delivery: Credentials and Future Trends
}

Umashankar MS and Satheesh Madhav NV

\begin{abstract}
Over the last few decades pharmaceutical scientists throughout the world are trying to explore transdermal and transmucosal routes as an alternative to injections. The main impediment for the oral delivery of the drugs as potential therapeutic agents is their extensive pre-systemic metabolism, instability in acidic environment associated with inadequate and erratic oral absorption. The parenteral route is the only established route that overcomes all the drawbacks related with the orally inefficient drugs. However the parenteral formulations are expensive, need frequent administration, with less patient compliance and other harmful effects. Since ancient times oral transmucosal drug delivery has received intensive interest for the systemic delivery of drugs proved to have better systemic bioavailability achieved by oromucosal route. Oral mucosal drug delivery provides an alternative method of systemic drug delivery which offers many advantages for both parenterals and oral methods. The oral mucosa is highly vascularised, hence
\end{abstract}

drugs which are absorbed through the oral mucosa directly enter into the systemic circulation, bypassing the enzymes present in the gastrointestinal tract and first-pass metabolism in the liver. The various transmucosal sites available are sublingual and buccal, but also the soft-palatal mucosa was found to be the most convenient and easily accessible novel site for the delivery of therapeutic agents for systemic delivery as retentive dosage forms. It has adequate blood supply, rapid cellular recovery time after exposure to stress, flexible, smooth surface, devoid of mechanical irritation, local discomfort and non-invasive route. Recently soft palate route explore more attention towards the scientist as an alternative to buccal route for administering drugs using mucoadhesive drug delivery dosage forms. This review focuses the more recent advances in novel soft palate route and formulation strategies to design dosage forms to administer drug through this novel soft palate route.

Keywords: Transmucosal delivery, soft palate, permeability and novelistic platform
Umashankar MS

Department of Pharmaceutics, SRM College of Pharmacy, SRM University, Kattankulathur, 603203, Kancheepuram district, TamilNadu, India. Corresponding author: HYPERLINK “mailto:umashankarshri2003@yahoo. co.in” umashankarshri2003@yahoo.co.in

Satheesh Madhav NV

Faculty of Pharmacy, Dehradoon Institute of Technology, Mussorie diversion Road, Bagawantpur, Makkawala, Dehradoon, Uttarakhand 248009, India. This work was carried out with the support rendered by the respectful Dean, Prof. Dr. KS Lakshmi, SRM College of Pharmacy, SRM University.

\section{INTRODUCTION}

The oral route of drug delivery is highly acceptable amongst the various routes of drug delivery and the most preferred by the patient and the clinician. The lack of efficacy of certain drugs especially peptides and proteins due to decreased bioavailability, unpredictable and erratic absorption, GI intolerance, or pre-systemic elimination as well as hepatic first pass metabolism and enzymatic degradation within the GI tract, that prohibit oral administration of certain classes of drugs which has prompted the search for other potential route for administration. A recent investigation of mucosal delivery of drugs for a large number of drugs had proved to be more promising. The mucosal linings of the nasal, rectal, vaginal, ocular, and oral cavity offer transmucosal routes of drug delivery with distinct advantages over peroral 
administration for systemic drug delivery. These routes possibly bypass first-pass metabolism of drugs, avoidance of pre-systemic elimination within the GI tract and, depending on the particular drug, a better enzymatic flora for drug absorption.

The oral cavity, on the other hand, is easily accessible by patients, the mucosa is relatively permeable with a rich blood supply, it is robust and shows short recovery times after stress or damage [1-30], and the virtual lack of Langerhans cells [4] makes the oral mucosa tolerant to potential allergens. Furthermore, oral transmucosal drug delivery bypasses first pass effect and avoids pre-systemic elimination in the GI tract. These factors make the oral mucosal cavity a very attractive and feasible site for systemic drug delivery. The oral mucosa can be categorized into sublingual, gingival, buccal and softpalatal mucosa through which systemic transmucosal drug delivery can be achieved.

Conventional buccal and sublingual dosage forms are typically short acting because of limited contact time between the dosage form and the oral mucosa. Since administration of drugs through these routes interferes with eating, drinking and talking therefore, thes e routes are generally considered unsuitable for prolonged administration, whereas softpalatal medication delivers steady infusion of drugs over an extended period of time, because of the function of the soft palate to cover the glottis while swallowing, it is more fitted for sustained and controlled drug delivery also due to the presence of immobile mucosa and lack of permeability in comparison with sublingual mucosa. Even though the sublingual mucosa is relatively more permeable than the buccal mucosa but it is not suitable for an oral transmucosal delivery system because it lacks an expanse of smooth muscle and is constantly washed by a considerable amount of saliva making it difficult for device placement. Because of high permeability and rich blood supply, the sublingual route is capable of producing a rapid onset of action making it appropriate for drugs with short delivery period requirements with infrequent dosing regimen. While buccal drug delivery has low flux due to less permeability which results in low drug bioavailability, other drawbacks include salivary dilution of the drug and inability to localize the drug within a specific site of the oral cavity. A novel Velar or soft palate as a route for drug delivery proved to be a smart site with its anatomical position, surface area, existence of mucus layer, optimal thickness, non-keratinization, optimal permeability offers a favorable alternative to the other oromucosal routes for systemic drug delivery [5].Therefore soft-palatal drug delivery is a feasible approach for correcting salivary dilution and achieving absorption site localization to retain the drug on the mucosa using a bio-adhesive system.

\section{ORAL MUCOSAL SITE FOR DRUG DELIVERY}

2.1. Anatomy, physiology and properties of the oral mucosa

The oral mucosa is composed of an outermost layer of stratified squamous epithelium, intermediate layer, lamina propria followed by the submucosa as the innermost layer [6]. The epithelium is similar to stratified squamous epithelia found in rest of the body in that it has a mitotically active basal cell layer, advancing through a number of differentiating intermediate layers to the superfacial layers, where cells are shed from the surface of the epithelium. The structure and biochemistry of the oral epithelium are illustrated by Squier et al. [7, 8, and 9] and its biochemistry by Gerson et al. [10]. Oral mucosa can be categorized into sublingual, gingival, buccal and palatal mucosa. The oral mucosal thickness varies depending on the site: the buccal mucosa measures at 500$800 \mathrm{~mm}$, while the mucosal thickness of the hard and soft palates, the floor of the mouth, the ventral tongue and the gingiva measure at about $100-200 \mathrm{~mm}$. The mucosae of the gingivae and hard plate are keratinized and the mucosae of the soft palate, the sublingual and the buccal regions, are not keratinized. The non-keratinized epithelia are more permeable to water than the keratinized epithelia through which oral transmucosal drug delivery can be achieved.

Mucus is a viscoelastic gel-like secretion which contains mostly water-insoluble glycoprotein bound to the apical cell surface of the entire oral cavity and acts as a protective layer to the cells below [11]. It is chemically consisting of $95-99 \%$ water, proteins, enzymes, electrolytes and nucleic acids with a large peptide backbone with pendant oligosaccharide side chains whose terminally ends with either sialic or sulfonic acid or L-fructose. The oligosaccharide chains are covalently linked to serine and threonine along the polypeptide backbone. About $25 \%$ of the polypeptide backbone is without sugars, the so-called 'naked' protein region, which undergo enzymatic cleavage. The remaining $75 \%$ of the backbone is heavily glycosylated. The terminal sialic groups have a pKa value of 2.6 so that the mucin molecule should be viewed as a polyelectrolyte under neutral or acid condition. At physiological $\mathrm{pH}$ the mucin network may carry a significant negative charge because of the presence of sialic acid and sulfate, residues and this high charge density plays an important role in mucoadhesion $[12,13]$.

\subsection{Permeability}

The oral mucosa is composed of somewhat leaky epithelia intermediate between that of the epidermis and intestinal mucosa and there are considerable differences in permeability 
between different regions of the oral cavity because of the diverse structures and functions of the different oral mucosa. The permeability coefficient of a drug is a measure of the ease with which the drug can permeate a membrane. The permeability coefficient is a function of the membrane thickness (i.e., inverse to its thickness) degree of keratinization of the tissues, and the physicochemical properties of the drug like its molecular weight, size, and lipophilicity. This suggested rank order is based on the relative thickness and degree of keratinization of these tissues, with the sublingual mucosa being comparatively thin and non-keratinized, the soft palatal mucosa is non-keratinized and thin than buccal, the buccal is thicker and non-keratinized, and the hard palate is intermediate in thickness but keratinized. Drug permeability appears to be highest in the sublingual area and lowest at the gingival site [14]. It is recently believed that the permeability barrier in the oral mucosa is a result of intercellular material derived from the so-called membrane coating granules (MCG) $[15,16]$. This barrier exists in the outermost 200 $\mu \mathrm{m}$ of the superficial layer. In both keratinized and nonkeratinized epithelia, the limit of penetration corresponds with the level where the MCGs could be seen adjacent to the superficial plasma membranes of the epithelial cells. Due to the identical results were obtained in both keratinized and non-keratinized epithelia, keratinization is not a factor to play a significant role in the barrier function.

\subsection{Conventional route versus transmucosal route for drug delivery}

Drugs are preferred to administer traditionally and routinely by oral and by parenteral routes. Although generally convenient, both routes have a number of disadvantages, especially for the delivery of peptides and proteins, a class of drug that has been rapidly emerging over the last decades [17]. Orally administered drugs are exposed to harsh environment of the gastrointestinal tract, potential chemical and enzymatic degradation [18]. After gastrointestinal absorption the drug has to pass the liver, where, dependent on the nature of the drug, extensive first-pass metabolism can take place with subsequent rapid clearance from the blood stream [19]. Low permeability across the gastrointestinal mucosa is also often encountered for macromolecular drugs $[20,21]$. Parenteral administration avoids drug degradation in the gastrointestinal tract and hepatic first-pass clearance but due to pain or discomfort during injection, patient compliance is poor, particularly if multiple daily injections are required as e.g. in the insulin therapy [22]. Injection related side effects like tissue necrosis and thrombophlebitis also lead to low patient acceptability. In addition, administration by injection requires trained personnel which add to the relatively high costs of parenteral medication. Consequently, other absorptive mucosae are being considered as potential sites for drug administration including the mucosal linings of the nasal, rectal, vaginal, ocular, and oral cavity. These transmucosal routes of drug delivery offer distinct advantages over peroral administration for systemic drug delivery such as possible bypass of the first pass effect and avoidance of presystemic elimination within the GIT.

\subsection{Theories of mucoadhesion}

The most widely investigated group of mucoadhesives for transmucosal drug delivery systems are hydrophilic macromolecules containing numerous hydrogen bondforming groups [23]. The presence of hydroxyl, carboxyl or amine groups on the molecules favours adhesion. They are called "wet" adhesives they are activated by moistening and get adhere non-specifically to various surfaces. They may get over hydrated to form slippery mucilage unless water intake is restricted. There are two basic steps in mucoadhesion for dry or partially hydrated dosage forms [24]. First step is the "contact stage" where intimate contact is formed between the mucoadhesive and mucous membrane. Within the oral cavity the formulation can usually be readily placed into contact with the mucosal site and held in place to allow adhesion to occur. Second step is the "consolidation $\nabla$ stage where various physicochemical interactions occur to consolidate and strengthen the adhesive bond which leads to prolonged adhesion.

Mucoadhesion is a complex process and numerous theories have been postulated to the mechanisms of mucoadhesion. These theories include mechanical interaction, electrostatic, diffusion-interpenetration, adsorption and fracture processes [25], at the same time as undoubtedly the most widely accepted theories are founded upon surface energy thermodynamics and interpenetration/diffusion [26]. The wettability theory is mainly applicable to liquid or low viscosity mucoadhesive systems and is essentially a measure of the spreadability of the drug delivery system across the biological substrate [27]. The electronic theory describes adhesion occurs by means of electron transfer between the mucus and the mucoadhesive system due to differences in their electronic configuration. The electron transport between the mucus and the mucoadhesive results in the formation of a double layer of electrical charges at the mucus and mucoadhesive border, this results in the formation of attractive forces within this double layer [28]. According 
to fracture theory, the adhesive bond between systems is related to the force required to separate both surfaces from one another. This "fracture theory" relates the force for polymer detachment from the mucus to the strength of their adhesive bond. The bond fracture has been found to be greater when the polymer network strands are longer or if the degree of cross-linking within such as system is reduced [29]. According to adhesion theory, adhesion is defined as being the result of various surface interactions (primary and secondary bonding) between the adhesive polymer and mucus substrate. Due to chemisorption a primary bond results in adhesion due to ionic, covalent and metallic bonding, this is often undesirable due to their permanency nature [30]. The diffusion-interlocking theory proposes the time-dependent diffusion of mucoadhesive polymer chains into the glycoprotein chain network of the mucus layer. This is a two-way diffusion mechanism with penetration rate mainly depends upon the diffusion coefficient of both interacting polymers [31].

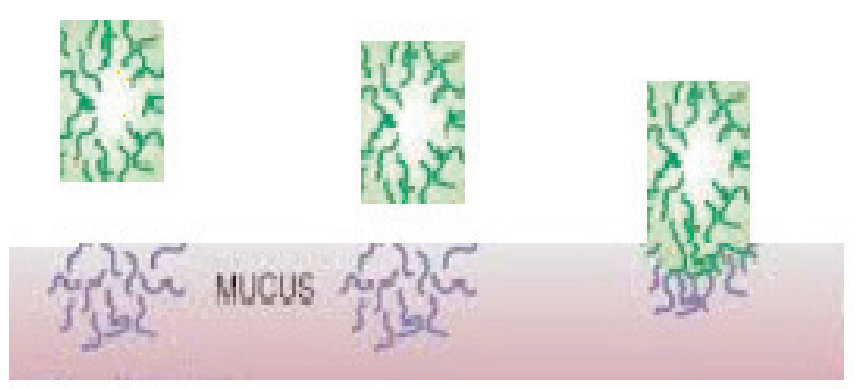

Fig 1. Interduffusion of polymer chain of mucoadhesive device through mucus

\subsection{Selected polymers for oro-soft palate mucoadhesive systems}

The polymer with a high rate of retention at the applied and targeted sites is through the mucoadhesive bonds which include hydrophilicity, negative charge potential and the presence of hydrogen bond forming groups. Furthermore, the surface free energy of the polymer should be adequate so that "wetting" with the mucosal surface can be achieved. The polymer should also possess sufficient flexibility to penetrate the mucus network, biocompatible, non-toxic and economic [32]. According to the literature survey mucoadhesive polymers are divided into first generation mucoadhesive polymers and second generation mucoadhesive polymers. The first generation polymers are divided into three major groups based on their surface charges which include anionic, cationic and non-ionic polymers. The anionic and cationic polymers exhibit stronger mucoadhesion [33]. Anionic polymers are the most widely used mucoadhesive polymers for various mucoadhesive formulations due to their high mucoadhesive strength and low toxicity. These polymers possess the major functional groups like carboxyl and sulphate groups which give rise to an overall net negative charge at $\mathrm{pH}$ values exceeding the $\mathrm{pKa}$ of the polymer. The classic examples include polyacrylic acid (PAA) and its derivatives and sodium carboxymethyl cellulose (Na CMC). PAA and $\mathrm{Na}$ CMC possess excellent mucoadhesive characteristics due to the formation of strong hydrogen bonding interactions with mucin [34]. Among the cationic polymer systems, chitosan is the most extensively investigated within the current scientific literature [35]. Chitosan is a cationic polysaccharide, produced by the deacetylation of chitin, the most abundant polysaccharide other than cellulose. Chitosan is a biopolymer due to its biocompatibility and biodegradability properties. Chitosan is reported to bind via ionic interactions between primary amino functional groups and the sialic acid and sulphonic acid substructures of mucus. The chemical derivitation can be done particular at the C-2 position formating a novel polymer with additional mucoadhesivity character. Using such modifications, the properties of chitosan may be tailored to suit the requirements of specific pharmaceutical technology challenges [36-38].

The term "cytoadhesives" belonging to second-generation polymer are less susceptible to mucus turnover rates, with directly binding to mucosal surfaces; more accurately. Surface carbohydrate and protein composition at potential target sites vary regionally with more accurate drug delivery can be achieved. Lectins are naturally occurring proteins that play a fundamental role in biological recognition phenomena involving cells and proteins. Soonafter the establishment of early mucosal cell-binding, lectins seems to remain on the cell surface or in the case of receptor-mediated adhesion probably become internalised via endocytosis [39]. Although lectins offer significant advantages towards targeting site, some are poisonous or immunogenic, and the effects of repeated lectin exposure are still unidentified. Thiolated polymers are a type of second-generation hydrophilic mucoadhesive polymers like chitosan, deacetylated gellan gum or polyacrylates. The presence of thiol groups allows the formation of covalent bonds with cysteine rich sub domains of the mucus gel layer which leads to augmented residence time along with enhanced bioavailability [40-42]. Whilst first-generation mucoadhesive platforms are facilitated via non-covalent secondary interactions, the covalent bonding mechanisms involved in second- generation systems undergo interactions 
that are less susceptible to changes in ionic strength and/or the $\mathrm{pH}$. A novelistic approach on various natural sources for polymer extraction was done from various following sources like coca nucifera, arachis hypogea seed, guava, tamarind, banana, lallimantia royalena, mango, lotus corniculatus, lusora etc. These have been proved to possess mucoadhesive characters and had been tried for its mucoadhesion on the soft palate site and also for drug release characters[43].

\section{ORO-SOFT PALATE}

\subsection{Histomorphology and positional environment of the soft palate}

The soft palate is a mobile flap hanging posteriorly the hard palate being anteriorly in the oral cavity, sloping down the back between the oral and nasal parts of the pharynx. The soft palate or velum is a muscular palate made of the soft tissue constituting the back of the roof of the mouth [44]. Velum route prevents mechanical irritation and local discomfort due to its smooth surface and good flexibility. The soft palate is a thick fold of mucosa enclosing an aponeurosis, muscular tissue, nerves, lymphoid tissue, mucous glands and two small pits, the fovea palatine, one on each side of the midline is present. The anterior (oral) concave surface of the soft palate makes it suitable for self administration of drug delivery system with the help of thumb $[45,46]$.

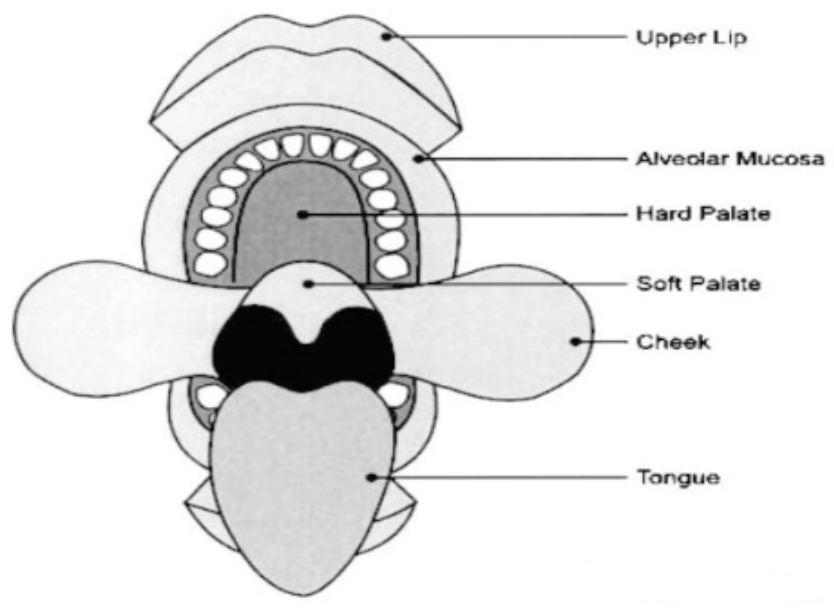

Fig.2. Position of the soft palate

The mucous membrane on the oral surface of the soft palate is highly vascularized. The papillae of the connective tissue are few and short, the stratified squamous epithelium is nonkeratinized, and the lamina propria shows distinctive layer of elastic fibers separating it from the submucous [4749]. Typical oral mucosa is continuous around the free border of the soft palate for a variable distance and is then replaced by nasal mucosa with its pseudo-stratified, ciliated columnar epithelium [50,51]. Oral side epithelium of the soft palate is covered consistently and uniformly with nonkeratinized stratified squamous epithelium of about 20-30 cell layers thick and which apparently withstand abrasive forces. The cell turnover time for the soft palate epithelium is about 5-6 days. The oral aspects of the palate, chiefly the anterior half are well gifted with seromucous glands, and small amounts of fatty tissues. The salivary glands secrets saliva around 750 $\mathrm{ml}$ which aid in moisturizing the palatal cavity to facilitate the dosage form adhesion [52]. These glandular secretions may serve as a glandular lubricant to reduce frictional forces. The ascending palatine branch of the facial artery and the greater palatine branch of the maxillary artery supply arterial blood to the soft palate. The blood supply by the facial artery to the palatal region is $0.89 \mathrm{ml} / \mathrm{min} / 100 \mathrm{~cm}^{2}$. The veins of the soft palate usually drain to the pterygoid venous plexus. The secretomotor supply to the majority of the mucosa of the soft palate moves via the lesser palatine nerve [53].The soft palate region, floor of the mouth, sublingual, labial and buccal mucosa are the major absorption sites in the oral cavity; secondly the hard palate and gingival.

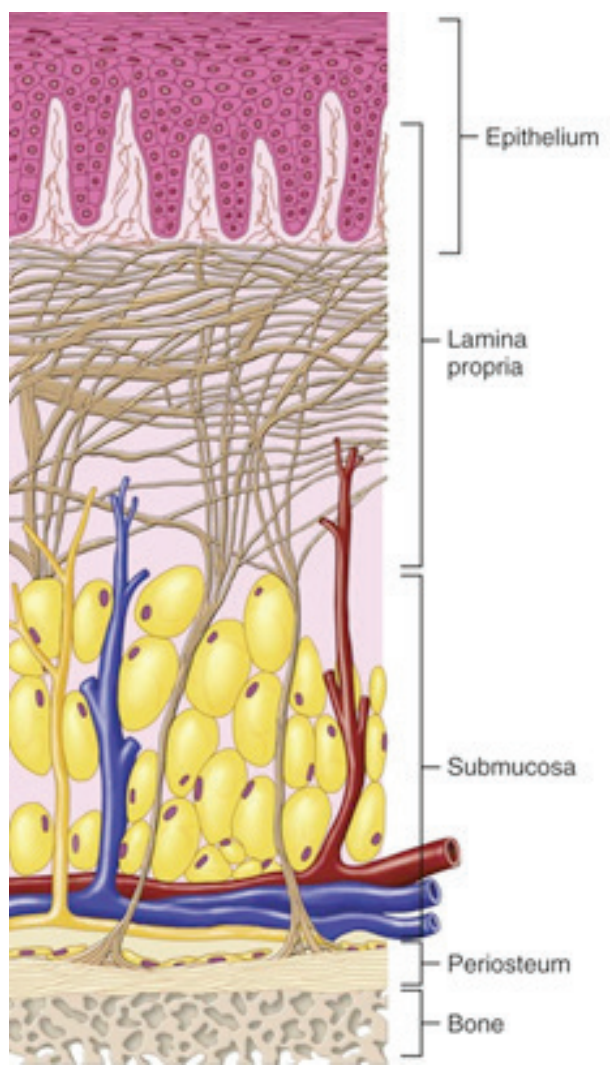

Fig.3. Histological overview of soft palate 


\subsection{Mucus physiology and its suitability}

The oral epithelium is surrounded by a thin layer of mucus, the principle constituents made up of proteins and carbohydrates actually play a role in mucoadhesion and act as a lubricant, allowing cells to move relative to one another and helps in bioadhesion of mucoadhesive drug delivery systems [54]. The soft-palatal mucosa composed of stratum squamous epithelial cells, with thickness of about 100-200 $\mu \mathrm{m}$ consists of a nonkeratinized epithelial tissue with the absence of acrylamides with small amounts of lipids like cholesterol and glycosyl ceramides. The oral soft-palate mucosal permeability is about 4-4000 times more than the skin and the thickness of the palatal mucosa $(158-224 \mu \mathrm{m})$ is intermediate between sublingual $(111 \mu \mathrm{m})$ and buccal $(594 \mu \mathrm{m})$ [55]. The mucosal $\mathrm{pH}$ of all oromucosal sites was ranged from $6.24 \pm 0.05$ to 7.36 \pm 0.06 and mean $\mathrm{pH}$ values in the palate, buccal mucosa and the lingual were $6.8 \pm 0.26,7.34 \pm 0.38$, and $6.28 \pm 0.36$, respectively. The mucosal $\mathrm{pH}$ aid in exploring as an optimal site for specific drug delivery since the palatal $\mathrm{pH}$ value $(7.34 \pm 0.38)$ is much more nearer to the $\mathrm{pH}$ value of blood as compared to the other oromucosal (buccal and sublingual) site and it also have the lowest salivary secretion measured by the Periotron method [56] emphasizing a major role in maintenance of suitable microenvironment because the salivary system is a powerful buffering system $[57,58]$ usually capable of possessing a stable intraoral $\mathrm{pH}$. The residual amounts of saliva on the oral mucosal tissues in the morning and afternoon were almost identical. The residual salivary thickness ranges from low of $0.16 \pm 0.03$ to high of $0.58 \pm 0.05$ in the lingual site; corresponding values for buccal ranged between $0.44 \pm 0.06$ to $1.13 \pm 0.05$ and 0.03 $\pm 0.003 \mathrm{~mm}$ on the soft palate [59]. Fortunately the enzyme activity is relatively low in the palatal mucosa comparatively with other mucosal area of the oral cavity $[48,55]$. Due to this more promising characteristic, the soft palate route proves to be fitted for oromucosal controlled and sustained release of drugs.

\subsection{Soft-palate mucosal suitability for drug diffusion}

The oral mucosa is believed to be 4-4000 times more permeable than that of skin [60]. Squier and co-workers [61] revealed that the permeability of water through the buccal mucosa was approximately 10 times more, whilst in floor of the mouth the permeability was approximately 20 times more than skin. Though oral mucosa elicits various physiological challenges, its unique structural and physiological properties present numerous opportunities for systemic drug delivery. The thickness of the mucus is dependent on its location [62]. The thickness of the mucus blanket depends on the balance between the rate of secretion and the rate of shedding. Toxins and irritants can stimulate mucus secretion to a greater extent, increasing the thickness of the mucus blanket while efficiently and rapidly moving the irritants away from the epithelium
[63-65]. Secreting new mucus is markedly more efficient than simply washing the surface, because rinsing the surface fails to refresh the unstirred layer adhering to the epithelium. In contrast, by continuously secreting new mucus, the unstirred layer is continuously and rapidly replaced. Convection is also inhibited by formation of a lipid-rich mucin layer at the surface of the gel [66] which helps in holding the drug-delivery systems in position at this site. Due to a little fluid movement within the gel, solutes are assumed to permeate only by diffusion. The size and arrangement of mucin fibers contributes drastically to the kinetics of the diffusion process [67-69].

\subsection{Factors affecting drug delivery through soft palate [70-76]}

The lipid solubility of drugs is a prime factor for soft palate drug delivery. However with better lipid solubility, drugs chosen for oro-soft palatal drug delivery must have physiochemical properties, drug size and $\mathrm{pKa}$ value possible for drug movement through the mucosa at a rate capable of producing required therapeutic blood concentrations. The rate of absorption of hydrophilic compounds is a function of the molecular size. Smaller molecules (75-100 Da) normally exhibit rapid transport across the mucosa, with permeability decreases as molecular size increases. A weakly acidic and weakly basic drug exhibit appreciable lipid solubility and thus has ability to cross lipoidal biomembrane. Greater the lipid soluble a compound, higher is its absorption. The ionization of a drug is directly related to both its $\mathrm{pKa}$ and $\mathrm{pH}$ at the mucosal surface. The drug must resist, or be protected by salivary and tissue enzymes that could cause inactivation. The drug and bioadhesive polymers should not damage the oral cavity and the surrounding tissues by keratinolysis, discoloration or irritation etc.

\subsection{Mechanism of drug transport via oro-soft palate}

Drug can be transported across oro-soft palate by passive diffusion, carrier-mediated, active transport or other specialized mechanisms. Most predominant absorption mechanism is passive diffusion across lipid membranes via either the paracellular or transcellular pathways (Figure 3) [77]. The hydrophilic nature of the paracellular spaces and cytoplasm provides a permeability barrier to lipophilic drugs but can be favourable for hydrophilic drugs. In contrast, the transcellular pathway involves drugs penetrating through one cell and the next until entering the systemic circulation. The lipophilic cell membrane offers a preferable route for lipophilic drugs compared to hydrophilic compounds. Drugs can transverse both pathways simultaneously although one route could be predominant depending on the physicochemical properties of the drug [78]. 


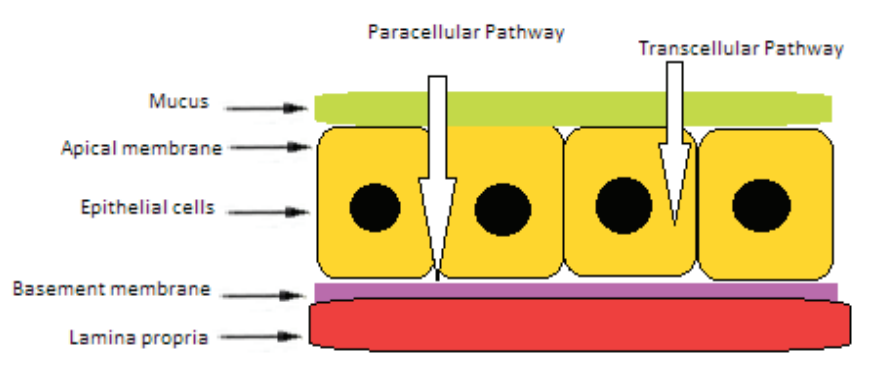

Fig 4. Mechanism of drug transport through soft palate mucosa

\section{SOFT PALATE DRUG DELIVERY TECHNOLOGY}

In the development of the soft palate drug delivery systems, mucoadhesion of the device is an important factor. Transmucosal drug-delivery system should rapidly attach to the mucosal surface and maintain a strong interaction without dislodgement. The term 'mucoadhesive' is usually meant for materials that bind to the mucin layer of a biological membrane. Mucoadhesive polymers can be utilized in efforts to achieve systemic delivery of drugs through the soft palate mucosae. Contact time should also be sufficiently long at the target site for complete drug release. As hydrophilic mucoadhesive polymers tend to lose adhesiveness upon hydration, restricted hydration and formation of a rigid gel network would be desirable for prolonged adhesion [79-87]. A short retention time, in relation to the drug release rate, will compromise bioavailability. The dosage form must provide reproducible effects at the retention site are also an important factor to be considered. An effective orotransmucosal drugdelivery system is that the mucoadhesion should not be impacted by surrounding $\mathrm{pH}$ of the site. Studies have shown that the bio-adhesiveness of polymers with ionizable groups is affected by the enivironment $\mathrm{pH}$, it is noted that palatal $\mathrm{pH}$ is much more nearer to the $\mathrm{pH}$ of blood as compared to the other oromucosal (buccal and sublingual) site which makes it a suitable site for mucoadhesive drug-delivery systems. The fact that these mucoadhesive polymers are stable in the acidic environment of the stomach and at $\mathrm{pH} \leq 7.4$ makes them ideal for targeted delivery to the palate, stomach and small intestine [88-96]. Mucoadhesive polymers should possess some general physiochemical features such as anionic hydrophilicity with hydrogen bond-forming groups, suitable surface wetting property with mucus/mucosal tissue surfaces and sufficient flexibility to penetrate the mucus network or tissue crevices for prolonged retention.

An ideal palatal drug-delivery system must meet several pre-requisites to be successful which is mainly depends on the mucoadhesive dosage forms, the potential impact of formulation excipients on the adhesive behavior of mucoadhesive drug-delivery systems and mucosal surfaces also should be carefully taken into account. For example, excipients containing hydroxyl groups could form hydrogen bonds with the hydrophilic functional group of mucoadhesive polymers and, as a result, prevent their interaction with the mucosal surface [97]. In addition, hydrophobic lubricants (e.g., magnesium stearate and talc) tend to hinder the formation of strong bio-adhesive bonds and thus reduce the mucoadhesive strength significantly [98]. Therefore, in developing a mucoadhesive transmucosal dosage form, palatal mucosa serves as an excellent platform for delivery of variety of APIs by the help of a mucoadhesion concept. Continuous research into the improvement of the oral transmucosal delivery of drugs has resulted in the development of several conventional and novel dosage forms like solutions, tablets/lozenges, chewing gums, sprays, patches and films, hydrogels, hollow fibres and microspheres. The more recent dosage forms include pillar implants (ref) and bioplates [99]. These Oral transmucosal systems for systemic drug delivery are usually designed to deliver the drug for either i) rapid drug release for immediate and quick action, ii) pulsatile release with rapid appearance of drug into systemic circulation and subsequent maintenance of drug concentration within therapeutic profile or iii) controlled release for extended period of time. The more appropriate factors for delivery systems are shown below Table 1 .

Table 1: Ideal factors for soft palatal drug delivery system design.

\begin{tabular}{ll}
\hline Factors & Explanation \\
\hline Size of the dosage form & $\begin{array}{l}\text { Dosage form should be of small size both } \\
\text { by height and width due to limited area } \\
\text { for mucoadhesion }\end{array}$ \\
$\begin{array}{l}\text { Low dose of the drug } \\
\text { molecule }\end{array}$ & $\begin{array}{l}\text { High dose may be problematic due to the } \\
\text { small surface area of soft palate }\end{array}$ \\
Mucosal adhesion & $\begin{array}{l}\text { Involuntary swallowing of the system } \\
\text { may possible if the mucoadhesion fails }\end{array}$ \\
Transport of drug across & $\begin{array}{l}\text { Drugs not absorbed by passive diffusion } \\
\text { cannot be administered }\end{array}$ \\
the soft palate mucosa & $\begin{array}{l}\text { pH of the palatal mucosa } 7.34 \pm 0.38 \\
\text { (close to blood pH) }\end{array}$ \\
pH of the absorption site & $\begin{array}{l}\text { Venous drainage is not subjected to he- } \\
\text { patic first-pass metabolism }\end{array}$ \\
Venous drainage of the & $\begin{array}{l}\text { Excipents with unpleasant taste, odour } \\
\text { mucosal tissues }\end{array}$ \\
Excipents for drug delivery & $\begin{array}{l}\text { It should maintain an intimate and pro- } \\
\text { longed contact of the formulation over } \\
\text { the site }\end{array}$ \\
Mucoadhesive agents & $\begin{array}{l}\text { Required to improve drug permeation } \\
\text { across mucosa } \\
\text { To protect the drug from the degradation } \\
\text { by some oral mucosal enzymes } \\
\text { It should be unidirectional drug release } \\
\text { to avoid wastage of drugs in the oral } \\
\text { cavity }\end{array}$ \\
Permeation enhancers & \\
Enzyme inhibitors &
\end{tabular}




\section{PERMEATION ENHANCERS SUITABLE FOR ORO- SOFT PALATE DELIVERY}

The permeability barrier is probably the greatest challenge to overcome in order to be able to fully utilize the oral mucosa as a site for drug delivery. Attempts to reduce this barrier have been researched in the form of permeability enhancers [100-102]. Permeation enhancers are also required when an API has to reach the systemic circulation through the transmucosal route to exert its action. They must be non-irritant and have a reversible effect. The most common classes of permeation enhancers used for the orotransmucosal route listed in the table. (Table 2).

Table 2: List of permeation enhancer and its mechanism of action [103]

\begin{tabular}{|c|c|c|c|}
\hline Classification & Examples & $\begin{array}{l}\text { Mode of } \\
\text { transport }\end{array}$ & $\begin{array}{c}\text { Mechanism of } \\
\text { action }\end{array}$ \\
\hline \multirow[t]{3}{*}{ Surfactants } & $\begin{array}{l}\text { Anionic } \\
\text { Sodium lauryl sulfate } \\
\text { Sodium laurate } \\
\text { Laureth-9 Sodium } \\
\text { dodecyl sulfate(SDS) } \\
\text { Dioctyl Sodium } \\
\text { sulfosuccinate }\end{array}$ & Paracellular & $\begin{array}{l}\text { Perturbation of inter- } \\
\text { cellular lipids, Protein } \\
\text { domain integrity }\end{array}$ \\
\hline & $\begin{array}{l}\text { Nonionic } \\
\text { Polyoxyethylene } \\
\text { 9lauryl ethe(PLE) } \\
\text { Tween80 Nonylp- } \\
\text { henoxypolyoxyet- } \\
\text { hylene(NPPOE) } \\
\text { Polysorbates Sodium } \\
\text { glycocholate }\end{array}$ & Paracellular & $\begin{array}{l}\text { Perturbation of } \\
\text { intercellular lipids, } \\
\text { Protein domain } \\
\text { integrity }\end{array}$ \\
\hline & $\begin{array}{l}\text { Cationic } \\
\text { Cetylpyridinium } \\
\text { chloride Chitosan, } \\
\text { trimethyl chitosan, } \\
\text { Poly L arginine, L }\end{array}$ & Paracellular & $\begin{array}{l}\text { Ionic interaction with } \\
\text { negative charge on } \\
\text { the mucosal surface }\end{array}$ \\
\hline $\begin{array}{l}\text { Fatty acids } \\
\text { and derivatives }\end{array}$ & $\begin{array}{l}\text { Oleic acid Caprylic } \\
\text { acid Mono(di)glyceri- } \\
\text { des Lauric acid Lino- } \\
\text { leic acid Acylcholi- } \\
\text { nes, Acylcarnitine }\end{array}$ & Paracellular & $\begin{array}{l}\text { Increase fluidity of } \\
\text { phospholipids } \\
\text { domains }\end{array}$ \\
\hline $\begin{array}{l}\text { Bile salts } \\
\text { and derivatives }\end{array}$ & $\begin{array}{l}\text { Sodium deoxycholate } \\
\text { Sodium taurocholate } \\
\text { Sodium taurodihyd- } \\
\text { rofusidate(STDHF) } \\
\text { Sodium glycodihyd- } \\
\text { rofusidate Sodium } \\
\text { glycocholate Sodium } \\
\text { deoxycholate }\end{array}$ & Paracellular & $\begin{array}{l}\text { Perturbation of } \\
\text { intercellular lipids, } \\
\text { Protein domain } \\
\text { integrity }\end{array}$ \\
\hline Sulfoxides & $\begin{array}{l}\text { Dimethyl sulfoxi- } \\
\text { de(DMSO) Decyl- } \\
\text { methyl sulfoxide }\end{array}$ & Paracellular & $\begin{array}{l}\text { Perturbation of } \\
\text { intercellular lipids } \\
\text { Protein domain } \\
\text { integrity }\end{array}$ \\
\hline $\begin{array}{l}\text { Chelating } \\
\text { agents }\end{array}$ & $\begin{array}{l}\text { EDTA Citric acid } \\
\text { Salicylates }\end{array}$ & Paracellular & Interfere with $\mathrm{Ca} 2+$ \\
\hline $\begin{array}{l}\text { Monohydric } \\
\text { alcohols }\end{array}$ & Ethanol Isopropanol & Paracellular & $\begin{array}{l}\text { Disrupt arrangement } \\
\text { of intercellular lipids }\end{array}$ \\
\hline Polyols & $\begin{array}{l}\text { Propylene glycol } \\
\text { Polyethylene glycol } \\
\text { Glycerol Propanediol }\end{array}$ & Paracellular & \\
\hline $\begin{array}{l}\text { Others } \\
\text { (nonsurfac- } \\
\text { tants) }\end{array}$ & $\begin{array}{l}\text { Urea and derivative } \\
\text { Unsaturated cyclic } \\
\text { urea Azone(1dode- } \\
\text { cylazacycloheptan2 } \\
\text { one) (laurocapram) } \\
\text { Cyclodextrin }\end{array}$ & Paracellular & $\begin{array}{l}\text { Perturbation of } \\
\text { intercellular lipids, } \\
\text { Protein domain } \\
\text { integrity }\end{array}$ \\
\hline
\end{tabular}

\subsection{Ideal characteristics of Permeation Enhancers $[104,105]$}

- It should enhance the permeation of the poorly diffusible drugs

- It should be pharmacologically inert

- It should be chemically stable

- It should be compatible with other excipients and drugs

- It should be non toxic, non irritant and non allergic

- It should be biocompatible and biodegradable

Though, soft palate drug delivery penetration route assessment is significant because it has smooth and flexible surface which is more appropriate for a better permeability of the drug with the use of a suitable permeation enhancer.

\subsection{Mechanisms of action of permeation enhancers [106,107]}

The effect of penetration enhancers for mucosal absorption revealed by various literature sources revealed that the altered rheological behavior with a varying thickness of viscoelastic layer of the mucus often due to the changing environment of the oral cavity eventually affects drug absorption. Additionally, saliva covering the mucus layers also hinders the absorption. Permeation enhancers act by diminishing the viscosity of the mucus and saliva thereby overcoming the barrier for drug absorption however, the most favored mechanism of mucosal drug absorption is intracellular route. Some permeation enhancers disturb the intracellular lipid layers, increasing the fluidity of lipid bilayer membrane by interaction with lipid or protein components so that the drug delivery is facilitated. Permeation enhancers act on desmosomes, a chief component at the tight junctions of the cells causing enhanced absorption of poorly absorbed drugs. Permeation enhancers also act by overcoming the enzymatic barrier by blocking the action of various peptidases and proteases present in the mucosa. In addition with change in membrane fluidity also modify the enzymatic activity indirectly. Some permeation enhancers increase the solubility of the drugs by changing the partition coefficient of the drug. This leads to improved thermodynamic activity resulting in improved drug absorption.

\section{ORAL SOFT PALATE MUCOSAL DOSAGE FORM STRATEGIES}

The development of "non-attached" or "mobile" drug-delivery system is that would be physically maintained within the oral cavity in contact with a mucosal surface by a conscious 
effort by the patient. Three types of non-attached drugdelivery systems are can be indentified are fast dissolving tablets, medicated chewing gum, drug loaded microporous hollow fibers [110-118]. However these delivery systems proved to be feasible for administration through the oral mucosa, there are some limitations. Research in this area has focused on the development of retentive oral mucosal drug delivery systems. A tremendous research has done by developing novel dosage forms for prolonging the duration of the absorption process. This impose that the dosage form should be remain sufficiently for a certain period of time and should release the drug in a controlled manner with a sufficient drug concentration delivered via the oral mucosa. To achieve this, a suitable drug delivery strategy is the design of "bioadhesive/immobilized" drug delivery system which can be retained on the mucosal surface by the use of suitable adhesive system $[108,109]$.

\subsection{Bioadhesive drug-delivery system}

In recent years several bioadhesive dosage forms for oral mucosal drug administration have developed and some are available commercially. The subject of intensive research in this newest area is the one which offer advantage over non-attached systems for oral delivery. These include: (i) the immobilisation permit an intimate contact to be developed between the drug dosage form and the mucosa; (ii) a high drug concentration maintenance at the absorptive surface for a prolonged period of time; (iii) the dosage form can be immobilised specifically at major parts of the mucosa like buccal, labial, sublingual, palatal or gingival mucosa; and (iv) the system itself can protect the drug from environmental degradation.

The design of bioadhesive oral mucosal drug-delivery systems is relatively difficult because it is necessary to have two definite properties to the delivery system (i) Immobilisation (ii) Controlled drug release. Such dual properties within a single system can be attained by the use of smart polymers. By the concept of bioadhesion or mucoadhesion by using adhesive smart polymers it is possible to achieve the both immobilisation and controlled or sustained release of the drug. Development of mucoadhesive drug delivery systems intended for oral administration has been more growing area recent research. A pioneering approach was made by formulating mucoadhesive bioplate for soft palatal delivery of gentamicin and amikacin using natural mucaodehsive material extracted from various fruits and kernels/seeds $[45,46,51,52]$. Various immobilized drug delivery systems are shown below (Table 3 ).
Table 3: Different types of immobilized drug delivery systems.

\begin{tabular}{ll}
\hline Immobilized system & References \\
\hline Powders & {$[91]$} \\
Microspheres & {$[92]$} \\
Tablets & {$[94-108]$} \\
Hydrogels & {$[109-115]$} \\
Film & {$[16-117]$} \\
Patches & {$[118-122]$} \\
Bioplate & {$[45,46,52]$} \\
\hline
\end{tabular}

\section{EXPERIMENTAL MODEL FOR THE SOFT PALATAL DRUG PERMEATION STUDY $[46,51,52]$}

Selection of an appropriate formulation for the delivery of drug through orosoft palatal mucosa depends mainly on the absorption criteria of the API. Due to which an in vitro palatal mucosal absorption study should also be performed. Palalatal mucosal tissue of the animal which closely resembles the histology of the human soft palate mucosa can be selected for the study. As soon as the animal is slaughtered soft palate is dissected and removed carefully by clearing off all the tissues debris. The isolated soft palate tissue is stored in a refrigerator at about $4-5^{\circ} \mathrm{C}$ in Kreb's buffer or Ringer lactate solution until used. The isolated and preserved soft palate tissue is mounted on a diffusion study apparatus to study for the drug permeation using appropriate buffer solution. The tissue viability and integrity can be assessed by the permeation study that if the drug permeability does not change throughout the study time under a specified experimental $\mathrm{pH}$ and temperature, then the tissue is considered to be viable since it a great concern during the in vitro diffusion study. Similarly in vivo study can also be performed for the drug permeation study through the palatal mucosa.

\section{ADVANTAGES OF THE SOFT PALATE DRUG DELIVERY}

Soft palate is highly vascularized site with low enzyme activity as compared to other oral mucosal regions.

Rapid cellular recovery of the mucosa is an advantage for drug delivery.

Devoid of mechanical irritation and local discomfort due to its smooth surface and good flexibility.

It avoids the acid hydrolysis of drug in the GIT.

It can reduce hepatic side effects of drugs and avoid first pass metabolism.

Soft palatal medication can delivers steady infusion of drugs over an extended period. 
Adverse effects and therapeutic failures frequently associated with intermittent dosing can be avoided.

Daily low dose of the drug can be elicited with equivalent therapeutics effect as compared with orally administered drug.

Drug showing poor and erratic absorption from the stomach or intestine can be administered via this route.

Therapeutic serum concentration can be achieved rapidly with greater bioavailability

Permeability coefficient is consistently higher in comparison to normal and hydrated skin.

Permeation enhancers or Peptide stabilizers can be used to modify the drug release from the dosage forms.

It can overcome the inconvenience caused by pain, tissue damage, and probable inflection by parenteral route.

Self medication is possible with proper patient counseling and termination of the drug delivery is achieved by removal of the dosage form from the site.

It provides a high patient acceptability as comparatively over other non-oral routes of drug administration.

\section{LIMITATIONS OF SOFT PALATAL DELIVERY}

Muco-irritatable APIs and drugs are not suitable for delivery. Drugs which are unstable at oral $\mathrm{pH}$ cannot be administered via this route.

Drugs not absorbed by passive diffusion cannot be administered.

Drug having unpleasant taste and odor cannot be administered.

Inconvenience of dosage forms while eating or drinking.

Accidental swallowing of the dosage system, if mucoadhesion fails.

Dislodgement of bioadhesive device due to overhdyration and swelling.

Loss of drug in the saliva, if the dosage form is not protected by impermeable backing membrane.

Surgical repair of soft palate tissue impose problem placing the dosage form.

\section{COUNSELING STEPS FOR PLACING THE DOSAGE FORM}

Place the dosage form over the thumb

Locate the soft palate in the upper roof of the mouth

Attach the dosage form over the soft palate surface with minimal pressure

Remove the thumb gently leaving the adhered dosage form over the soft palate

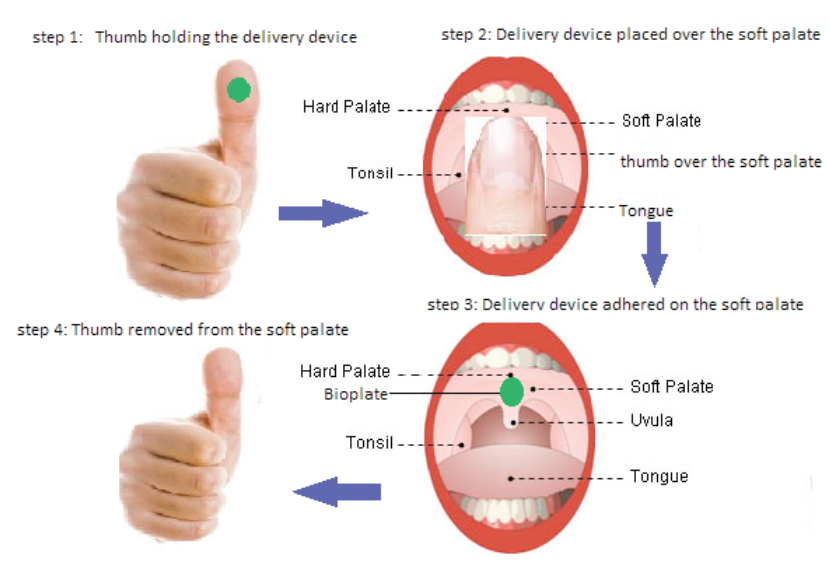

\section{FUTURE PERSPECTIVES}

The oral route has undergone considerable research for the drug delivery. The other delivery routes chasing behind through research using novel formulations. Soft palatal site is a promising area for continued research with the aim of systemic delivery of orally inefficient drugs as well as a feasible and attractive alternative for non-invasive delivery of protein and peptides. Although mobilized drug delivery systems are available in the market with few beneficial effects towards the drug delivery in the oral cavity they impose some limitations. Immobilized drug delivery systems are still to achieve their persona through oral transmucosal delivery. There is a need and challenge of needle-free vaccine delivery to obtain enhanced immunity. Research focuses on overcoming the hurdles of vaccine delivery towards an alternative delivery systems, tailored adjuvant technologies and novel route of administrations. Presently, invasive mode of vaccines administered via the parenteral route can trigger the systemic immune response analogous as that of parenterally-delivered vaccine. The effective mucosal vaccines will not provide adequate mucosal immune protection. At this juncture it is important to examine the development of mucosal vaccination strategies that can effectively trigger systemic as well as mucosal immunity. The potential of the soft palate site can be extended for the delivery of vaccines using nanocarrier systems such as multiple emulsions, liposomes, nanoparticles, and dendrimers etc. However a need for safe and effective permeation/absorption enhancers is essential for permeability through transsoft palatal mucosa. Rational design of formulations for soft palate drug delivery needs further attention towards vehicle property, polymeric nature that optimizes the retention, controlled release and noninvasive delivery of drugs. The use of lipids, nanostructured materials and amorphous form of 
API and solid dispersions on a micro or nanoscale may be the technology of the future for orosoft palatal delivery.

\section{CONCLUSION}

The oral cavity for long has been a site of medicinal application in order to treat diseases in the mouth itself. The soft palatal site offers promising scope for controlled drug delivery. The mucosa possesses both vascular and lymphatic drainage. The soft palate delivery avoids first pass metabolism and presystemic elimination of the drug. This novel site is well suited for bioadhesive drug delivery devices and proves to be accepted by the patient. With the tailor-made device loaded with appropriate dose of the drug systemic delivery can be achieved in a controlled manner adapting with mucosal surface

Oral-yumuşak damak mukozasına uygulanan akıllı ilaç taşıyıcılar: Veriler ve geleceğin trendleri

\section{ÖZET}

Son ylllarda, dünyanın her yerinde eczacılık alanında çalışan bilim adamları, enjeksiyonlara alternatif olarak transdermal ve transmukozal yolları araştırmaya çalışıyorlar. İlaçların potansiyel terapötik ajan olarak oral uygulanmalarındaki esas engel, bunların yüksek oranda presistemik olarak metabolize olmaları, yetersiz ve değişken oral absorbsiyonla birlikte asidik ortamda da stabil olmamalarıdır. Parenteral yol, oral olarak etkisiz ilaçlarla ilgili bütün çekincelerin üstesinden gelen tek yoldur. Bununla birlikte, parenteral formülasyonlar pahalıdır, daha az hasta uyuncu ve diğer zararlı etkilerle birlikte sık uygulama da gerektirir. Oral transmukozal ilaç taşınması eski çağlardan beri ilaçların sistemik uygulanmasında yoğun ilgi görmüş, oromukozal yolla daha iyi sistemik biyoyararlanım sağlandığı kanıtlanmıştır. Oral mukozal ilaç taşınması, sistemik ilaç taşınması için hem parenteral hem de oral yöntemlere göre birçok avantaj sunan alternatif bir yol sağlar. Oral mukoza yüksek oranda vaskülarizedir, dolayısıyla ilaçlar gastrointestinal permeability and environment. A pioneering approach was made by formulating mucoadhesive bioplate for soft palatal delivery of gentamicin and amikacin and evaluated for its mucoretentability and drug permeability which revealed more promising results. The soft palatal offers a choice of noninvasive route for protein and peptides delivery. In near future this novel platform certainly gains more significance and motivate researchers both from academia and industry.

\section{Acknowledgements}

This work was carried out with the support rendered by the respectful Dean, Prof. Dr. K.S. Lakshmi, SRM College of Pharmacy, SRM University. Authors are very grateful to the Dean for the successful completion of this review article. bölgedeki enzimleri ve karaciğerdeki ilk geçiş etkisini atlayarak, oral mukozadan absorblanır ve doğrudan sistemik dolaşıma geçer. Dilaltı ve bukkal bölge absorbsiyon için uygun transmukozal alanlardır, bundan başka terapötik ajanların sistemik uygulanması için çok uygun ve kolaylıkla erişilebilir yeni bir alan olarak yumuşak damak mukozası da bulunmuştur. $\mathrm{Bu}$ alan yeterli kan akımına sahip, strese maruziyet sonrası hızlı selüler düzelme gösteren, mekanik iritasyonun olmadığ 1 esnek ve düz yüzeye sahip olmasiyla birlikte, lokal rahatsılık oluşturabilecek ve girişimsel olmayan bir yoldur. Son zamanlarda yumuşak damak yolu, mukoadezif ilaç taşıyıcı dozaj şekillerini kullanarak ilaç uygulanması için bukkal yola alternatif olarak bilim adamlarının daha çok dikkatini çekmektedir. Bu derleme yeni yumuşak damak yolundaki ve ilaçları bu yeni yumuşak damak yoluyla uygulamaya yönelik dozaj formları tasarlamak için kullanılan formülasyon stratejilerindeki daha güncel gelişmelere odaklanmıştır.

Anahtar kelimeler: Transmukozal ilaç taşıma, yumuşak damak, permeabilite ve yenilikçi platform

\section{REFERENCES}

1. Rathbone MJ, Hadgraft J. Absorption of drugs from the human oral cavity. Int J Pharm 1991; 74: 9-24.

2. De Vries ME, Bodde HE, Verhoef JC, Junginger HE. Developments in buccal drug delivery, Crit Rev Ther Drug Carrier Syst 1991; 8: 271-303.

3. Bodde HE, De Vries ME, Junginger HE. Mucoadhesive polymers for the buccal delivery of peptides, structureadhesiveness relationships, J Control Release 1990; 13: 225-31.

4. Gandhi RB, Robinson JR. Oral cavity as a site for bioadhesive drug Adv Drug Deliv Rev 1994; 13: 43-74.

5. Squier CA, Wertz PW. Structure and Function of the Oral Mucosa

and Implications for Drug Delivery. In: Oral Mucosal Drug Delivery. Editor: Rathbone MJ, Marcel Dekker. New York. 1996, pp 1-25.

6. Smart JD. Lectin-mediated drug delivery in the oral cavity. Adv Drug Deliv Rev 2004;56: 481-9.

7. Siegel A. Permeability of the Oral Mucosa. In: The Structure and the Function of Oral Mucosa Editors: Meyer J, Squier CA, Gerson SJ, Pergamon Press. Oxford. 1976, pp 7-15.

8. Squier CA, Johnson NW, Hopps RM. The Organization of Oral Mucosa, Human Oral Mucosa, Development, Structure and Function. Blackwell Scientific Publications, Oxford. 1976, pp. 7-15.

9. Chen SY, Squier CA. The Ultrastructure of the Oral Epithelium. 
In: The Structure and Function of Oral Mucosa. Pergamon Press, Oxford. 1984, pp. 7-30.

10. Gerson KW, Harris RR. The Structure and Function of Oral Mucosa. In: The Structure and Function of Oral Mucosa. Pergamon Press, Oxford. 1984, pp. 31-518.

11. Bell AA, McQueen S. Mucus and Mucosal Protection. In: Mechanisms of Mucosal Protection in the Upper Gastrointestinal Tract Editors: Bell AA, Flemstro G, Garner A, Silen W, Turnberg LA, Raven Press. New York. 1984, pp. 195-202.

12. Lehr CM. From sticky stuff to sweet receptors--achievements, limits and novel approaches to bioadhesion. Eur J Drug Metab Pharmacokinet 1996;21: 139-48.

13. Haas J, Lehr CM. Developments in the area of bioadhesive drug delivery systems. Expert Opin Biol Ther 2002; 2: 287-98.

14. Squier CA, Johnson NW. Permeability of oral mucosa. Br Med Bull 1975; 31: 169-75.

15. Squier CA, Eady RA, Hopps RM. The permeability of epidermis lacking normal membrane-coating granules: an ultrastructural tracer study of Kyrle-Flegel disease. J Invest Dermatol 1978; 70: 361-4.

16. Squier CA, Hall BK. The permeability of mammalian nonkeratinized oral epithelia to horseradish peroxidase applied in vivo and in vitro. Arch Oral Biol 1984;29: 45-50.

17. Siegel IA, Hall SH, Stambaugh R. Permeability of Oral Mucosa. In: Current Concepts of the Histology of Oral Mucosa. Editors: Squier CA, Meyer J, Carles Thomas. Springfield. 1971, pp 274286.

18. Zhoua XH, Li Wan PA. Peptide and protein drugs: II. Nonparenteral routes of delivery. Int J Pharm 1991; 75: 117-130.

19. Bertram U, Bodmeier R. In situ gelling, bioadhesive nasal inserts for extended drug delivery: in vitro characterization of a new nasal dosage form. Eur J Pharm Sci 2006; 27: 62-71.

20. Shen DD, Kunze KL, Thummel KE. Enzyme-catalyzed processes of first-pass hepatic and intestinal drug extraction. Adv Drug Deliv Rev 1997; 27: 99-127.

21. DeMeo MT, Mutlu EA, Keshavarzian A, Tobin MC. Intestinal permeation and gastrointestinal disease. J Clin Gastroenterol 2002; 34: 385-96.

22. Varshosaz J. Insulin delivery systems for controlling diabetes, recent patents on endocrine, Metab. Immune Drug Discov. 1 (2007) 25-40.

23. Woodley J. Bioadhesion: new possibilities for drug administration? Clin Pharmacokinet 2001;40: 77-84.

24. Lee JW, Park JH, Robinson JR. Bioadhesive-based dosage forms: the next generation. J Pharm Sci 2000; 89: 850-66.

25. Smart JD. The basics and underlying mechanisms of mucoadhesion. Adv Drug Deliv Rev 2005; 57: 1556-68.

26. Andrews GP, Laverty TP, Jones DS. Mucoadhesive polymeric platforms for controlled drug delivery. Eur J Pharm Biopharm 2009; 71: 505-18.

27. Madsen F, Eberth K, Smart JD. A rheological assessment of the nature of interactions between mucoadhesive polymers and a homogenised mucus gel. Biomaterials. 1998; 19:1083-92.

28. Ugwoke MI, Agu RU, Verbeke N, Kinget R. Nasal mucoadhesive drug delivery: background, applications, trends and future perspectives. Adv Drug Deliv Rev 2005; 57:1640-65.

29. Dodou D, Breedveld P, Wieringa PA. Mucoadhesives in the gastrointestinal tract: revisiting the literature for novel applications.Eur J Pharm Biopharm. 2005; 60: 1-16.

30. Ahagon A, Gent AN. Effect of interfacial bonding on the strength of adhesion. J Polym Sci Polym Phys 1975; 13: 12851300.

31. Jimenez-Castellanos MR, Zia H, Rhodes CT. Mucoadhesive drug delivery systems. Drug Dev Ind Pharm 1993; 19: 143-94.

32. Lee JW, Park JH, Robinson JR. Bioadhesive-based dosage forms: the next generation. J Pharm Sci. 2000; 89: 850-66.

33. Shojaei AH, Li X. Mechanisms of buccal mucoadhesion of novel copolymers of acrylic acid and polyethylene glycol monomethylether monomethacrylate J Control Rel 1997; 47: 151-61.

34. Ludwig A. The use of mucoadhesive polymers in ocular drug delivery. Adv Drug Deliv Rev 2005; 57: 1595-639.

35. Fefelova NA, Nurkeeva ZS, Mun GA, Khutoryanskiy VV.Mucoadhesive interactions of amphiphilic cationic copolymers based on [2-(methacryloyloxy)ethyl] trimethylammonium chloride. Int J Pharm 2007;339: 25-32.

36. Portero A, Teijeiro-Osorio D, Alonso M, Remuñán-López C. Development of chitosan sponges for buccal administration of insulin, Carbohydr Polym 2007;68: 617-25.

37. Rossi S, Ferrari F, Bonferoni MC, Caramella C. Characterization of chitosan hydrochloride-mucin interaction by means of viscosimetric and turbidimetric measurements. Eur J Pharm Sci 2000;10: 251-7.

38. Bernkop-Schnürch A. Chitosan and its derivatives: potential excipients for peroral peptide delivery systems. Int J Pharm 2000; 194: 1-13.

39. Clark MA, Hirst BH, Jepson MA. Lectin-mediated mucosal delivery of drugs and microparticles. Adv Drug Deliv Rev 2000;43: 207-23.

40. Leitner VM, Walker GF, Bernkop-Schnürch A. Thiolated polymers: evidence for the formation of disulphide bonds with mucus glycoproteins. Eur J Pharm Biopharm 2003;56: 207-14.

41. Albrecht K, Greindl M, Kremser C, Wolf C, Debbage P, Bernkop-Schnürch A. Comparative in vivo mucoadhesion studies of thiomer formulations using magnetic resonance imaging and fluorescence detection. J Control Release 2006; 115: 78-84.

42. Roldo M, Hornof $\mathrm{M}$, Caliceti $\mathrm{P}$, Bernkop-Schnürch A. Mucoadhesive thiolated chitosans as platforms for oral controlled drug delivery: synthesis and in vitro evaluation. Eur J Pharm Biopharm 2004; 57: 115-21.

43. He P, Davis S, Illium 1 . In vitro evaluation of the mucoadhesive properties of chitosan microspheres. Int J Pharm 1998; 166: 75-88.

44. Waugh A, Grant A. Anatomy and physiology in health and illness. Churchill Livingstone. China. 2006.

45. Satheesh NV, Uma Shankar MS. A novel oro-soft palatal platform for transmucosal gentamicin delivery. Proceedings of ICSS. Jadavpur University, 13 February 2008. 
46. Satheesh NV, Uma Shankar MS, Maurya A. Smart Bioplate from Lallimantia royalena seeds for Trans-soft Palatal Delivery, Proceedings of International Conference on Innovations in Drug Delivery. from Biomaterial to Devices, Italy, 30 September-3 October 2007.

47. Ahuja A, Khar RK, Ali J. Mucoadhesive drug delivery systems. Drug Dev Ind Pharm 1993; 19: 143-94.

48. Ali J, Khar RK, Ahuja A, Kalra R. Bucoadhesive erodible disk for treatment of orodental infections: design and characterisation. Int j Pharm 2002; 238:93-103.

49. Chien YW. Novel drug delivery system, mucosal drug delivery: potential routes for noninvasive systemic administration. Marcel Dekker, New York. 1992.

50. Chowdary KPR, Srinivas L. Mucoadhesive drug delivery system: a review of current status Ind Drugs 2000; 37:400-6.

51. Satheesh NV, Uma Shankar MS. A Smart Flexiplate for Oral Transmucosal Soft Palatal Delivery of Amikacin. Proceedings of the International world PSWC, Netherlands, 22-23 April 2007.

52. Satheesh NV, Uma Shankar MS. A Smart Soft Palatal Platform for Oral Transmucosal Delivery by Using Drugloaded Mangifera indica. Proceedings of bioplate-Indian Pharmaceutical Congress, BHU 23-25 December 2007.

53. Oral histology, inheritance and development. Editors: Provenza DV, Seibel W. Lea \& Febiger. Philadelphia. 1996.

54. Paulsen F, Thale A. Epithelial-connective tissue boundary in the oral part of the human soft palate. J Anat 1998; 193:457-67.

55. Dhaneshwar K, Rathi L, Avinash M, Yogesh A. A review on oral mucosal drug delivery system. Int J Pharm Sci Res 2010; 1:50-6.

56. DiSabato-Mordarski T, Kleinberg I. Measurement and comparison of the residual saliva on various oral mucosal and dentition surfaces in humans. Arch Oral Biol 1996; 41:655-65.

57. Eliasson L, Birkhed D, Heyden G, Strömberg N. Studies on human minor salivary gland secretions using the Periotron method. Arch Oral Biol 1996; 41:1179-82.

58. Kocevar-Nared J, Kristl J, Smid-Korbar J. Comparative rheological investigation of crude gastric mucin and natural gastric mucus. Biomaterials 1997; 18:677-81.

59. Specian RD, Neutra MR. Mechanism of rapid mucus secretion in goblet cells stimulated by acetylcholine. J Cell Biol 1980; 85:626-40.

60. Squier CA, Cox P, Wertz PW. Lipid content and water permeability of skin and oral mucosa. J Invest Dermatol 1991; 96:123-6.

61. Squier CA, Wertz PW. Structure and function of the oral mucosa and implications for drug delivery. In: O ral Mucosal Drug Delivery. Editor: Rathbone MJ, Marcel Dekker Inc. New York. 1996, pp 1-26.

62. Soft palate or velum, Avaliable in: http://global.britannica. com/science/soft-palate

63. Yuichi T, Kazaharu M, Kazuyuki S. Anatomy of muscles which construct the soft palate. Ann Kagoshima Univ Dental School 2006; 26:21-6.

64. Verma S, Kaul M, Rawat A, Saini S. An overwiev on buccal drug delivery system. IJPSR 2011; 2:1303-21.

65. Gandhi RE, Robinson JR. Bioadhesion in drug delivery. Ind J Pharm Sci 1988; 50:145-52.

66. Harris D, Robinson JR. rug delivery via the mucous membranes of the oral cavity. J Pharm Sci 1992; 81:1-10.

67. Wertz PW, Squier CA. Cellular and molecular basis of barrier function in oral epithelium.Crit Rev Ther Drug Carrier Syst 1991; 8: 237-69.

68. Morales JO, McConville JT. Novel strategies for the buccal delivery of macromolecules. Drug Dev Ind Pharm 2014; 40:579-90.

69. Hwang SR, Byun Y. Advances in oral macromolecular drug delivery. Expert Opin Drug Deliv 2014; 11:1955-67.

70. Du JD, Liu Q, Salentinig S, Nguyen TH, Boyd BJ. A novel approach to enhance the mucoadhesion of lipid drug nanocarriers for improved drug delivery to the buccal mucosa. Int J Pharm 2014; 471:358-65.

71. Galey WR, Lonsdale HK, Nacht S. The in vitro permeability of skin and buccal mucosa to selected drugs and tritiated water. J Invest Dermatol 1976; 67:713-7.

72. Nguyen S, Hiorth M. Advanced drug delivery systems for local treatment of the oral cavity. Ther Deliv 2015; 6:197-210.

73. Satheesh Madhav NV, Hossain E, Uma Shankar SU. "A Novelistic Trans-Soft Palatal Route for Smart Drug Delivery of Gentamicin by Mucoadhesive Plates". Proceedings of $17^{\text {th }}$ Singapore Pharmacy Congress, Singapore, 1-4 July 2005.

74. Satheesh Madhav NV, Uma Shankar MS, Hossain E. "Soft Palate-A Novel Platform For Transmucosal Delivery Of Amickacin". Proceedings of International Conference on Ethnopharmacology and Alternative Medicine, Amla Cancer Institute-Trissur, 20 January 2006.

75. Schär D, Ramseier CA, Eick S, Arweiler NB, Sculean A, Salvi GE. Anti-infective therapy of peri-implantitis with adjunctive local drug delivery or photodynamic therapy: six-month outcomes of a prospective randomized clinical trial. Clin Oral Implants Res 2013; 24:104-10.

76. Sattar M, Sayed OM, Lane ME. Oral transmucosal drug delivery--current status and future prospects. Int J Phar 2014; 471:498-506.

77. Rathbone MJ, Tucker IG. Mechanisms, barriers and pathways of oral mucosal drug permeation. Adv Drug Deliv Rev 1993; 12:41-60.

78. Galey WR, Lonsdale HK, Nacht SY. Permeability studies on buccal mucosae. J Invest Dermatol 1976;67:713-17.

79. Marriot C, Hughes DRL. Mucus Physiology and Pathology Bioadhesion-Possibilities and Future Trends. Wissenschaftliche-Verlagsgesellschaft mbH, Stuttgart-1990, pp. 29-43.

80. Puchelle E. Rheology, biochemistry and functions of mucus. Biorheology 1987; 24:411-23.

81. Verdugo P. Goblet cells secretion and mucogenesis. Annu Rev Physiol 1990;52:157-76.

82. Allen A, Hutton DA, Pearson JP, Sellers LA. Mucus glycoprotein structure, gel formation and gastrointestinal mucus function. Ciba Found Symp 1984; 109:137-56. 
83. Nagai T, Konishi R. Buccal/gingival drug delivery systems. J Control Rel 1987; 6:353-60.

84. Webber W. Mucosal Drug Delivery, Buccal. In: Encyclopedia of Controlled Drug Delivery. Editor: Mathiowitz E, John Wiley and Sons. Inc, New York. 1999, 553- 563.

85. Gupta A, Garg S, Khar R K. Mucoadhesive drug delivery systems: A Review. Ind Drugs 1992; 29:586-93

86. Goswami S K. Bioadhesive dosage forms: An overview. The Eastern Pharmacist 1994; 15:85-7.

87. Agarwal S, Aggarwal S. Mucoadhesive polymeric platform for drug delivery; a comprehensive review. Curr Drug Deliv 2015;12:139-56.

88. Weatherell J A, Colin R, Rathbone M J. Site specific differences in the salivary concentrations of substances in the oral cavityImplications for the aetiology of oral disease and local drug delivery. Adv Drug Deliv Rev 1994; 13:23-42.

89. Shojaei AH. Buccal mucosa as a route for systemic drug delivery: a review. J Pharm Pharm Sci 1998; 1:15-30.

90. Salamat-Miller N, Chittchang M, Johnston TP. The use of mucoadhesive polymers in buccal drug delivery. Adv Drug Deliv Rev 2005; 57:1666-91.

91. Laffleur F. Mucoadhesive polymers for buccal drug delivery. Drug Dev Ind Pharm. 2014; 40:591-8.

92. Sudhakar Y, Kuotsu K, Bandyopadhyay AK. Buccal bioadhesive drug delivery--a promising option for orally less efficient drugs. J Control Release 2006; 114:15-40.

93. Bruschi ML, de Francisco LM, S de Toledo Lde A, Borghi FB.An overview of recent patents on composition of mucoadhesive drug delivery systems. Recent Pat Drug Deliv Formul 2015;9:79-87.

94. Rathbone M J, Drummond BK, Tucker IG. Oral cavity as a site for systemic drug delivery. Adv Drug Deliv Rev 1994; 13: 1-22.

95. Nangia A. Science and technology of bioadhesive-based targeted oral delivery systems. . Pharm Technol 2008; 32: 10021.

96. Chickering DE, Mathiowitz E. Definitions, Mechanism, and Theories of Bioadhesion, Bioadhesive Drug Delivery System. Editors: Mathiowitz E, Chickering DE, Lehr CM, Marcel Dekker. New York. 1999, pp 1-10.

97. Mortazavi AA, Moghimi HR. The effect of hydroxyl containing tablet excipients on the adhesive duration of some mucoadhesive polymers. DARU 2004; 12:11-7.

98. Tobyn MJ, Johnson JR, Dettmar PW. Factors affecting in vitro gastric mucoadhesion: influence of tablet excipients, surfactants and salts on the observed mucoadhesion of polymers. Eur J Pharm Biopharm 1997; 43:65-71.

99. N.V. Satheesh Madhav and M. S. Uma Shankar. A Novel biopolymeric smart stabilizer from Cocos Nucifera meat kernel and its pharmaceutical applications. Indian Patent Application filed 2007-09-25/2018/DEL/2007, published; 05-23.

100. Steward C, Bayley DL, Howes C. The effect of enhancers on the buccal absorption of hybrid (BDBB) alpha-interferon. Int J Pharm 1994; 104:145-9.

101. Senel S, Hincal AA. Drug permeation enhancement via buccal route: possibilities and limitations. J Control Release 2001;
72:133-44.

102. Moser K, Kriwet K, Naik A, Kalia YN, Guy RH. Passive skin penetration enhancement and its quantification in vitro. Eur $\mathrm{J}$ Pharm Biopharm 2001; 52:103-12.

103. Benediktsdóttir BE, Baldursson Ó, Másson M. Challenges in evaluation of chitosan and trimethylated chitosan (TMC) as mucosal permeation enhancers: From synthesis to in vitro application. J Control Release 2014; 173:18-31.

104. van der Lubben IM, Verhoef JC, Borchard G, Junginger HE. Chitosan and its derivatives in mucosal drug and vaccine delivery. Eur J Pharm Sci 2001; 14:201-7

105. Chopra S, Mahdi S, Kaur J, Iqbal Z, Talegaonkar S, Ahmad FJ. Advances and potential applications of chitosan derivatives as mucoadhesive biomaterials in modern drug delivery. J Pharm Pharmacol 2006; 58:1021-32.

106. Bernkop-Schnürch A. Mucoadhesive systems in oral drug delivery. Drug Discov Today Technol 2005; 2: 83-7.

107. Rossi S, Sandri G, Caramella CM. Buccal drug delivery: A challenge already won? Drug Discov Today Technol 2005; 2:59-65.

108. Zhang H, Zhang J, Streisand JB. Oral mucosal drug delivery: clinical pharmacokinetics and therapeutic applications. Clin Pharmacokinet 2002; 41:661-80.

109. Gilles P, Ghazali FA, Rathbone J. Systemic Oral Mucosal Drug Delivery Systems and Delivery Systems. In: Oral Mucosal Drug Delivery. Editor: Rathbone MJ, Marcel Dekker. New York. 1996, pp 241-285.

110. Christrup LL, Rasmussen SN, Rassing MR. Chewing gum as a drug delivery system. IV. Excretion of ascorbic acid in urine after administration of chewing gum and chewing tablets. Farmaci Scientific Edition 1988; 16:44-67.

111. Jensen LN, Christrup LL, Menger N, Bundgaard H. Chewing gum and lozenges as delivery systems for noscapine. Acta Pharm Nord 1991; 3:219-22.

112. Russell MA, Raw M, Jarvis MJ. Clinical use of nicotine chewing-gum. Br Med J 1980; 280:1599-602.

113. Graffner C. Some Clinical Results with Respect to Buccal Administration. Minutes European Symposium on Buccal and Nasal Administration as an Alternative to Parenteral Administration, Paris, 10-11 December. 1991.

114. Benowitz NL, Jacob P 3rd, Savanapridi C. Determinants of nicotine intake while chewing nicotine polacrilex gum. Clin Pharmacol Ther 1987; 41:467-73.

115. Christrup LL, Bonde J, Eriksen H, Rasmussen SN, Rassing MR, Simonsen K. Bioavailability of salicylamide administered in tablets and chewing gum. Farmaci Scientific Edition 1988; 16:6-14.

116. Christrup LL, Bonde J, Rasmussen SN, Rassing MR. Relative bioavailability of (+/-)-verapamil hydrochloride administered in tablets and chewing gum. Acta Pharm Nord 1990; 2:371-6.

117. Jain SK, Jain A. Target-specific drug release to the colon. Expert Opin Drug Deliv 2008; 5:483-98.

118. Burnside BA, Keith AD, Snipes W. Microporous hollow fibers as a peptide delivery system via the buccal cavity. Proc Int Symp Control Rel Bioact Mater 1989; 16:93-4. 